the transglycosylase would be to attach such a complex to a template strand and, by stepwise cleavage of the strand, move the complex along the strand while the other enzymes take care of the synthesis and inser- tion of adjacent, new peptidoglycan strands. A similar multi-enzyme complex could also take care of the formation and precise cutting of the cell wall septum ${ }^{22}$ that occurs during cell division. The existence of multi- enzyme complexes in Gram-positive bacteria has never been demonstrated: experiments will tell whether PBP2x is part of such a multienzyme complex in the Gram-positive $S$. pneumoniae.
1. Pares, S., Mouz, N., Pétillot, Y., Hakenbeck, R. \& Dideberg, O. Nature Struct. Biol. 3 284-289 (1996).

2. Kucers, A. \& Bennett, N.M. in The use of antibiotics: a comprehensive review with clinical emphasis 1-585 (William Heinemann Medical Books, London, 1987).

3. Neu, H.C. Science 257, 1064-1073 (1992)

4. Chin, G.J. \& Marx, J. (eds.) Science 264, 360-393 (1994).

5. Weidel, W. \& Pelzer, H. Adv. Enzymol. 26, 193-232 (1964)

6. van Heijenoort, J. in Bacterial cell wall (eds. Ghuysen, J.-M. \& Hakenbeck, R.) 39-54 (Elsevier Science B.V., Amsterdam, 1994).

7. Höltje, J.-V. \& Schwarz, U. in Molecular Cytology of Escherichia coli 77-119 (Academic Press, London, 1985)

8. Matsuhashi, M. in Bacterial cell wall (eds. Ghuysen, J.-M. \& Hakenbeck, R.) 55-71
(Elsevier Science B.V., Amsterdam, 1994).

Jamin, M., Bamblon, C., Millier, S., Hakenbeck R. \& Frère, J.-M. Biochem. J. 292, 735-741 (1993).

10. Kitano, K., Tuomanen, E. \& Tomasz, A. FEMS Microbiol. Lett. 7, 759-765 (1986).

11. Kelly, J.A. et al. J. Biol. Chem. 260, 6449-6458 (1985).

12. Kelly, J.A. \& Kuzin, A.P. J. Mol. Biol. 254 , 223-236 (1995).

13. Strynadka, N.L. et al. Nature Struct. Biol. 3 , 290-297 (1996).

14. Service, R.F. Science 270, 724-727 (1995).

15. Gale, E.F.E., Cundliffe, E., Reynolds, P.E., Richmond, M.H. \& Waring, M.J. in The molecular basis of antibiotic action 49-120 (John Wiley \& Sons, New York, 1972).

16. Fan, C., Moews, P.C., Walsh, C.T. \& Knox, J.R. Science 266, 439-443 (1994).

17. Benson, T.E., Filman, D.J., Walsh, C.T. \& Hogle,
J.M. Nature Struct. Biol. 2, 644-653 (1995)

Benson, T.E., Walsh, C.T. \& Hogle, J.M Structure 4, 47-54 (1996)

19. Romeis, T \& Höltie, J.V. Eur I Biochemi. 224 597-604 (1994)

20. Thunnissen, A.M.W.H. et al. Nature 367, 750-753 (1994)

21. Thunnissen, A.-M.W.H. PhD. Thesis, Groningen Universtiy (1995)

Wientjes, F. \& Nanninga, N. J.Bacteriol. 171 3412-3419 (1989)

23. Schleifer, K.H. Meths Enzymol. 18, 123-156 (1985).

24. Labischinski, H. \& Maidhof, H. in Bacterial cell wall (eds. Ghuysen, J.-M. \& Hakenbeck, R.) 23-38 (Elsevier Science B.V., Amsterdam, 1994)

25. Glauner, B., Höltje, J.-V. \& Schwarz, U. J. Biol. Chem. 263, 10088-10095 (1988).

26. Garcia-Bustos, J.F, Chait, B.T. \& Tomasz, A. J. Biol. Chem. 262, 15400-15405 (1987).

\title{
Bundled up against the heat
}

Histones are the first-line managers of the cellular structure of all eucaryotic chromosomes, organizing DNA into nucleosomes. In general, procaryotes must rely on other means, perhaps as

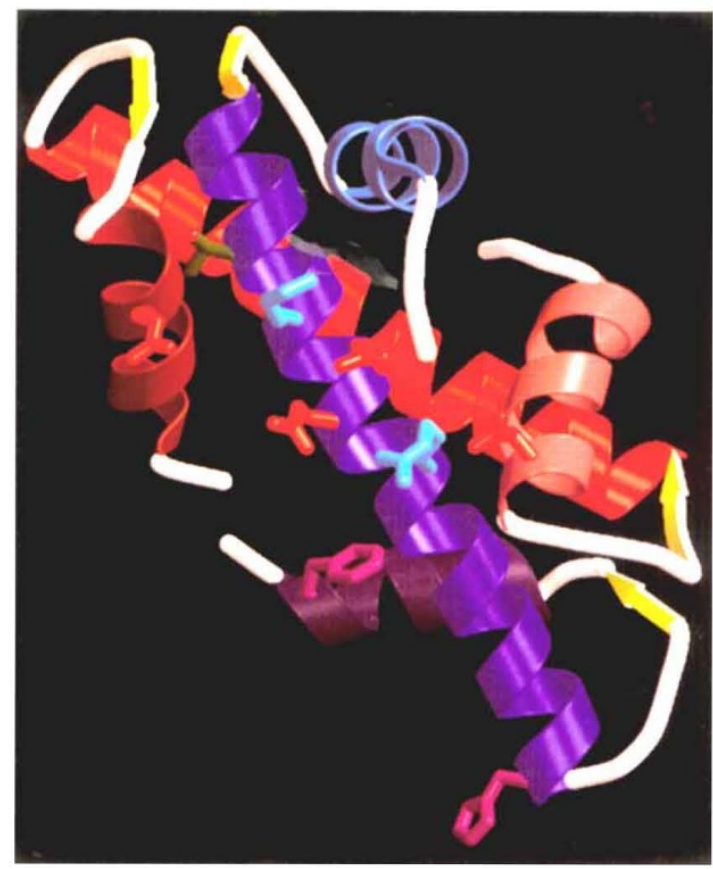
befits the relative simplicity of their genomes. However, one division of the procaryotes, the archaea, do have histones, based on the homology of sequence, function, and now structure-as reported by Mary R Starich, Kathleen Sandman, John N Reeve and Michael F Summers in J. Mol. Biol. 255, 187-203 (1996) and shown in the picture-lending further credence to the idea that eucaryotes descended from archea.

The NMR structure of the histone HMfB, from Methanothermus fervidus, confirms that it functions as a dimer (one monomer shown with red helices, the other with blue). An individual monomer possesses the classical 'histone fold' seen in more prosaic organisms, like chickens. The solution dimer resembles the $\mathrm{H} 2 \mathrm{~A}-\mathrm{H} 2 \mathrm{~B}$ or $\mathrm{H} 3-\mathrm{H} 4$ dimers in eucaryotes.

$M$. fervidus is an extreme thermophile, and living in temperatures in excess of $80^{\circ} \mathrm{C}$ presents it with special challenges. Strategically positioned residues (side chains shown in the picture) may lend stability to the dimer through hydrogen bonds and salt bridges. For example, an electrostatic interaction between Arg 37 in the long helix (blue) of one monomer and Asp 14 in helix 1 of the other (pink) may help keep the $\mathrm{C}$ termini tacked down. 